\title{
Induction of Ovulation by Hormone Treatment in Ussurian Bullhead Leiocassis ussuriensis
}

\author{
Sang Gu Lim ${ }^{\dagger}$, Young Soo Kim, Hyung Kyun Han, Kwang Suk Kim, \\ Dae Jung Kim, Eon Jong Kang, Sang Gyu Son and Eung Oh Kim \\ Inland Aquaculture Research Institute, NFRDI, Kyeongsangnam-do 645-806, Korea
}

\begin{abstract}
The effects of ovulation induction in ussurian bullhead, Leiocassis ussuriensis, were investigated by treating ussurian bullhead with hCG, LHRHa, GnRHa, ovaprim, and pimozide. hCG was injected to ussurian bullhead at $0.75 \%$ $\mathrm{NaCl}, 5,000,10,000,20,000$, and 30,000 IU, respectively. The ovulation inducement rates were $100 \%$ in 20,000 and 30,000 IU. Fertilization rates were $82.7 \%$ and $79.8 \%$. Hatching rates were $59.4 \%$ and $57.2 \%$. Ovulation time was between $16-19$ $\mathrm{hr}$ The concentrations of LHRHa injected were $0.75 \mathrm{NaCl}, 50,100,200,300$, and $300 \mu \mathrm{g} / \mathrm{kg}$. The ovulation inducement rates were $100 \%$ in 300 and $400 \mu \mathrm{g} / \mathrm{kg}$. Fertilization and hatching rates were $84.9 \%$ and $68.4 \%$ at $200 \mu \mathrm{g} / \mathrm{kg}$. The times to ovulation were between $23 \mathrm{hr}$ and $34 \mathrm{hr}$. Ovaprim of $0.75 \% \mathrm{NaCl}, 1.0,1.5,2.0,2.5$ and $3.0 \mathrm{ml} / \mathrm{kg}$ were injected to the abdominal cavity. The ovulation inducement rate was highest at 2.0 and $3.0 \mathrm{ml} / \mathrm{kg}$ to $92 \%$ and ovulation time was between 27-38 hr. LHRHa concentrations of $0.75 \% \mathrm{NaCl}, 50,100,200,300$ and $400 \mu \mathrm{g}$ were injected with pimozide $(1,000$ $\mu \mathrm{g})$. Ovulation inducement rate was $100 \%$ from 200 to $400 \mathrm{IU}$ with pimozide. Ovulation time was 22-36 h. Fertilization and hatching rates were $88.9 \%$ and $70.4 \%$ in $200 \mu \mathrm{g} / \mathrm{kg}$ with pimozide.
\end{abstract}

Key words : Ussurian bullhead, Leiocassis ussuriensis, HCG, LHRHa, Ovaprim, Pimozide, Ovualation induction, Ovulation time

\section{INTRODUCTION}

Ussurian bullhead Leiocassis ussuriensis is fish that belongs to family Bagridae and is found in Daedong river, Amnok river, Imjin river, Han river, and Geum river. It has recently been found in nakdong river as well (Kim, 1997). They are nocturnal fish that live in rivers with slow current and in river bottom composed of mud or sand. With their chewy flesh and excellent taste of umami, they are essential in cooking fresh water spicy fish stew, along with the Korean bullhead.

As the reduction in available habitat due to recent environment pollution and development of rivers and flood have accelerated the decline of resources, it is necessary to work on resource recovery and increase in

\footnotetext{
4 Corresponding author: Sang Gu Lim, Inland Aquaculture Research Institute, NFRDI, Kyeongsangnam-do 645-806, Korea. Phone: +8255-540-2723, Fax: +82-55-546-6292, E-mail: sklim391@korea.kr
}

production in a timely manner. The most important and fundamental mission to do for the restoration of ussurian bullhead is to develop seedling production techniques by obtaining fertile eggs through artificial maturation and ovulation. To induce maturation and ovulation in fish species that does not naturally give birth indoors, hormones are artificially injected. And it is of great importance to inject the right type of hormone using the right method depending on the target species. Hormones that are currently being used in order to induce fish maturation and ovulation are pituitary extracts from fish and frogs, human chorionic gonadotropin (hCG), gonadotropin (GTH) of fish, luteinizing hormone releasing hormone (LHRH) of mammals, luteinising hormone releasing hormone analogue (LH$\mathrm{RHa})$ that is known to be 30 to 50 times more effective than natural LHRH, and pimozide that is cheap and accessible (Park et al., 1998). These hormones in 
combination with pimozide has recently been used in bullhead (Silurus asotus, kwon et al., 1996), river puffer (Takifugu obscurus, Jang, 1996), and ussurian bullhead (Lim et al., 2012).

There have been studies on the species used in present study as a subject to the culture in the high value-added industry, such as the ultrastructure of spermatozoa of the ussurlan bullhead and phylogenetic discussion (Kim \& Lee, 2000), the early gonadogenesis and sex differentiation in the bagrid catfish (Park et al., 2001), and the difference in the growth between male and female of ussurian bullhead (Kang et al., 2003), but not on the artificial egg collection techniques. Since it is hard to induce natural births in Ussurian bullhead, the ovulation inducement rate, ovulation time, fertilization rate, and hatching rates at differing concentrations of hormones were investigated in this study to examine the effectiveness of LHRHa, hCG, ovaprim, and pimozide in ovulation inducement in order to develop artificial egg collection techniques and to use these data as the foundation of development of the seedling production of ussurian bullhead.

\section{MATERIALS AND METHODS}

Table 1. Body weight and ovulation time of ussurian bullhead used in experiment

\begin{tabular}{|c|c|c|c|c|}
\hline Hormone & \multicolumn{2}{|c|}{ Concentration } & "Body weight (g) & Ovulation time (h) \\
\hline \multirow{5}{*}{ hCG (IU/kg) } & \multicolumn{2}{|c|}{ Cont. } & $75.3 \pm 11.6$ & 0 \\
\hline & \multicolumn{2}{|c|}{5,000} & $77.8 \pm 10.7$ & $19^{\mathrm{b}}$ \\
\hline & \multicolumn{2}{|c|}{10,000} & $76.6 \pm 12.5$ & $18.5^{\mathrm{b}}$ \\
\hline & \multicolumn{2}{|c|}{20,000} & $82.6 \pm 10.9$ & $17.5^{\mathrm{a}}$ \\
\hline & \multicolumn{2}{|c|}{30,000} & $86.7 \pm 10.1$ & $17^{\mathrm{a}}$ \\
\hline & \multicolumn{2}{|c|}{ Cont. } & $78.2 \pm 9.5$ & 0 \\
\hline & \multicolumn{2}{|c|}{50} & $75.5 \pm 10.7$ & $34^{\mathrm{e}}$ \\
\hline & \multicolumn{2}{|c|}{100} & $81.9 \pm 9.2$ & $28.5^{\mathrm{d}}$ \\
\hline LHRHa $(\mu g / k g)$ & \multicolumn{2}{|c|}{200} & $78.8 \pm 11.7$ & $19.5^{\mathrm{b}}$ \\
\hline & \multicolumn{2}{|c|}{300} & $77.6 \pm 10.4$ & $16.5^{\mathrm{a}}$ \\
\hline & \multicolumn{2}{|c|}{400} & $81.2 \pm 19.2$ & $25^{\mathrm{c}}$ \\
\hline & \multicolumn{2}{|c|}{ Cont. } & $80.2 \pm 9.2$ & 0 \\
\hline & \multicolumn{2}{|c|}{1.0} & $78.4 \pm 9.8$ & $38^{\mathrm{d}}$ \\
\hline & \multicolumn{2}{|c|}{1.5} & $82.3 \pm 7.2$ & $35^{\mathrm{c}}$ \\
\hline Ovaprım (ml/kg) & \multicolumn{2}{|c|}{2.0} & $84.1 \pm 7.0$ & $36^{\mathrm{c}}$ \\
\hline & \multicolumn{2}{|c|}{2.5} & $76.9 \pm 6.7$ & $32^{\mathrm{b}}$ \\
\hline & \multicolumn{2}{|c|}{3.0} & $76.6 \pm 8.9$ & $28.5^{\mathrm{a}}$ \\
\hline \multirow{7}{*}{$\begin{array}{l}\text { LHRHa+Pimozide } \\
\qquad(\mu g / \mathrm{kg})\end{array}$} & $\mathrm{L}$ & $\mathrm{P}$ & & \\
\hline & Cont. & 0 & $81.1 \pm 8.8$ & 0 \\
\hline & 50 & 1,000 & $67.3 \pm 14.7$ & $33^{\mathrm{d}}$ \\
\hline & 100 & 1,000 & $76.9 \pm 6.2$ & $28.5^{\mathrm{c}}$ \\
\hline & 200 & 1,000 & $78.8 \pm 11.7$ & $27^{\mathrm{b}}$ \\
\hline & 300 & 1,000 & $65.6 \pm 16.5$ & $25.5^{\mathrm{a}}$ \\
\hline & 400 & 1,000 & $71.2 \pm 19.2$ & $24.5^{\mathrm{a}}$ \\
\hline
\end{tabular}


Dev. Reprod. Vol. 16, No. 4 (2012) Induction of Ovulation by Hormone Treatment in Ussurian Bullhead Leiocassis ussuriensis 273

\section{Experimental fish}

820 Fish (485 females and 335 males) born from natural mother between June $30^{\text {th }}, 2005$ and August $6^{\text {th }}$, 2008, were used and their weights are recorded in Table 1. Individuals with finished yolk accumulation were used. Once polyethylene cannula $(2.5 \mathrm{~mm}$ inner diameter) was injected into the ovarian cavity of ussurian bullhead with expanded abdominal, their oogonia were collected by suction, and they were then put in $10 \%$ formaldehyde solution (Duksan Pure Chemicals Co. LTD) in order for their maturity to be examined under the microscope.

\section{Hormone treatment}

In order to examine the influence of injections of hormones on fish, the concentrations of hCG and LHRHa used were 500, 10,000, 20,000, and 30,000 IU/kg and $50,100,200,300$, and $400 \mu \mathrm{g} / \mathrm{kg}$, respectively, and $0.75 \% \mathrm{NaCl}$ was used as control. The concentrations of ovaprim were $1.0,2.0,2.5$, and $3.5 \mathrm{ml} / \mathrm{kg}$ and thecombinations of LHRHa and pimozide were obtained by mixing $50,100,200,300$, and $400 \mu \mathrm{g} / \mathrm{kg}$ of LHRHa with $1,000 \mu \mathrm{g} / \mathrm{kg}$ of pimozide. Ovulation rate, ovulation time, fertilization rate, and hatching rate were examined.

hCG (Daesung Microbiological Labs. Co., LTD) was kept at $-20^{\circ} \mathrm{C}$ by dilution until the experiment. LHRHa (Sigma Co., USA), ovaprim (Sigma Co., USA) and pimozide (Sigma Co., USA) were dissolved with $0.75 \% \mathrm{NaCl}$ and then were kept at $-20^{\circ} \mathrm{C}$. The number of fish treated with each hormone was $76,92,80$, and 69, respectively. Different concentrations were first injected to dorsal muscles and then accommodated in the water bath for ovulation inducement. The dry method was used for fertilization of eggs obtained by abdominal pressure and sperms and hatching temperature was kept at $26+/-1{ }^{\circ} \mathrm{C}$. Fertilization and hatching rates were calculated by averaging those of randomly selected fertilized eggs.
Ovulation time was measured by lightly pressing on the abdominal region every hour and seeing if the eggs had been released, and only the individuals that released eggs smoothly were considered to be successes of ovulation inducement.

\section{Statistics}

Duncan's multiple range test and Kruskal-wallis test were used to analyze the change over time and the significance levels for all tests were less than 0.05 .

\section{RESULTS}

\section{Ovulation time by hormone treatment}

Treatment with hCG of $30,000 \mathrm{IU} / \mathrm{kg}$ resulted in the shortest ovulation time of $17 \mathrm{hr}$. Ovulation time increased as the concentration decreased, as the ovulation times were 19, 18.5, 17.5 at hCG concentrations of $5,000,10,000$, and 20,000 IU/kg, respectively. LHRHa showed a similar pattern as the ovulation times were $34,28.5,19.5$, and $25 \mathrm{hr}$ at concentrations of 50, 100, 200 , and $400 \mu \mathrm{g} / \mathrm{kg}$. The shortest ovulation time of $16.5 \mathrm{hr}$ was observed at LHRHa concentration of 300 $\mu \mathrm{g} / \mathrm{kg}$. It took, on average, $28.5 \mathrm{hr}$ for the eggs to ovulate at ovaprim of $3.0 \mathrm{ml} / \mathrm{kg}$, and $38,35,36$, and $32 \mathrm{hr}$ at ovaprim concentrations of 1.0, 1.5, 2.0, and $2.5 \mathrm{ml} / \mathrm{kg}$, respectively, showing the same pattern hCG also showed. When treated with the combinations of LHRHa and pimozide $(1,000 \mu \mathrm{g} / \mathrm{kg})$, at $400 \mu \mathrm{g} / \mathrm{kg}$ the ovulation time was $24.5 \mathrm{hr}$ and was the shortest. At 50, 100,200 , and $300 \mathrm{ml} / \mathrm{kg}$ of concentrations, the ovulation times were $33,28.5,27$, and 25.5 , respectively, leading to the common observation of decreasing ovulation time with increasing concentration of any hormone (Table 1).

\section{Ovulation rate by hormone treatment}

The ovulation rates at hCG concentrations of 20,000 $\mathrm{IU} / \mathrm{kg}$ and $30,000 \mathrm{IU} / \mathrm{kg}$ are $100 \%$. As it was $71.4 \%$ 
and $80 \%$ at $5,000 \mathrm{IU} / \mathrm{kg}$ and $10,000 \mathrm{IU} / \mathrm{kg}$, respectively, the ovulation rate tended to be higher at higher concentration. When treated with LHRHa that affects final maturation and ovulation, $100 \%$ of ovulation rate was reached at 300 and $400 \mu \mathrm{g} / \mathrm{kg}$, and at 50,100 , and $200 \mu \mathrm{g} / \mathrm{kg}$, the ovulation rate was $10,62.5$, and $75 \%$, respectively. Thus it showed the same pattern as hCG. Treatment with Ovaprim resulted in the highest ovulation rate of $92 \%$ at both 2.0 and $3.9 \mathrm{ml} / \mathrm{kg}$ of concentration and at the concentration of $1.0,1.5$, and 2.5 , the ovulation rate was 57,78 , and $86 \%$, respectively. Combinations of LHRHa and pimozide yielded $100 \%$ ovulation rate at LHRHa concentration of 200 , 300 , and 400 , and the lowest ovulation rate of $50 \%$ at $50 \mu \mathrm{g} / \mathrm{kg}$ (Fig. 1).

3. Fertilization rate and hatching rate by hormone treatment

When treated with hCG, the fertilization and hatching rates of $82.7 \%$ and $59.4 \%$ were the highest at $20,000 \mathrm{IU} / \mathrm{kg}$. The rates were the lowest when 5,000 $\mathrm{IU} / \mathrm{kg}$ was injected $(78.2 \%$ and $49.7 \%)$ but no significant difference was observed at other experimental groups. When LHRHa was injected, the fertilization rate of $85.3 \%$ was the highest at $300 \mu \mathrm{g} / \mathrm{kg}$ and the hatching rate of $68.4 \%$ was the highest at $200 \mu \mathrm{g} / \mathrm{kg}$. The lowest were $52.2 \%$ and $56.3 \%$ at 50 and $100 \mu$ $\mathrm{g} / \mathrm{kg}$, respectively. Treatment with Ovaprim yielded the highest fertilization rate of $88.2 \%$ at $2.0 \mathrm{ml} / \mathrm{kg}$ and the lowest hatching rate of $58.6 \%$ at $1.0 \mathrm{ml} / \mathrm{kg}$. In contrast to ovulation rate or ovulation time, the fertilization rate seemed to decrease with increasing concentration. The combinations of LHRHa and pimodize $(1,000 \mu \mathrm{g} / \mathrm{kg})$ resulted in the highest fertilization rate of $88.9 \%$ at 200 $\mu \mathrm{g} / \mathrm{kg}$ and the lowest hatching rate of $60.2 \%$ at $400 \mu$ $\mathrm{g} / \mathrm{kg}$, showing the same pattern as ovaprim (Fig. 2).

\section{DISCUSSION}

Artificial ovulation and spawning can be induced by
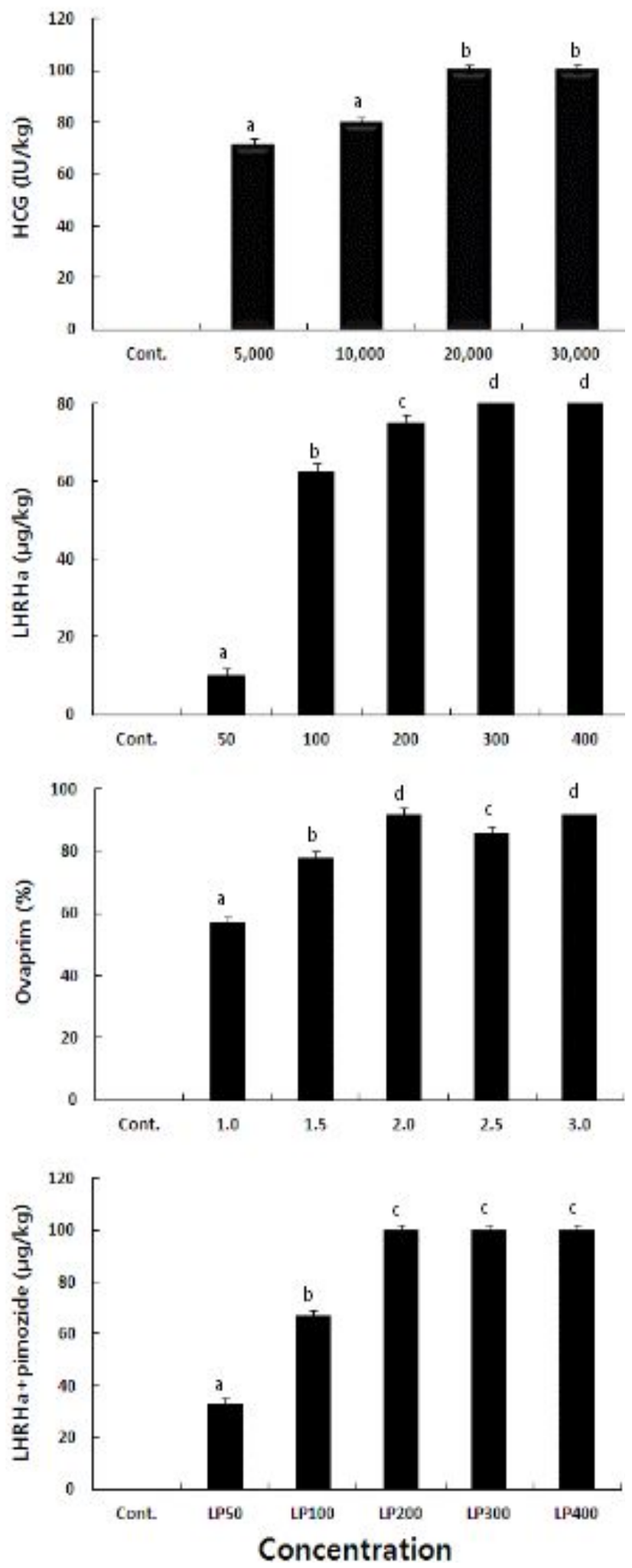

Fig. 1. Ovulation rates of ussirian bullhead in each hormones. Cont: control, LP: LHRHa+pimozide. 

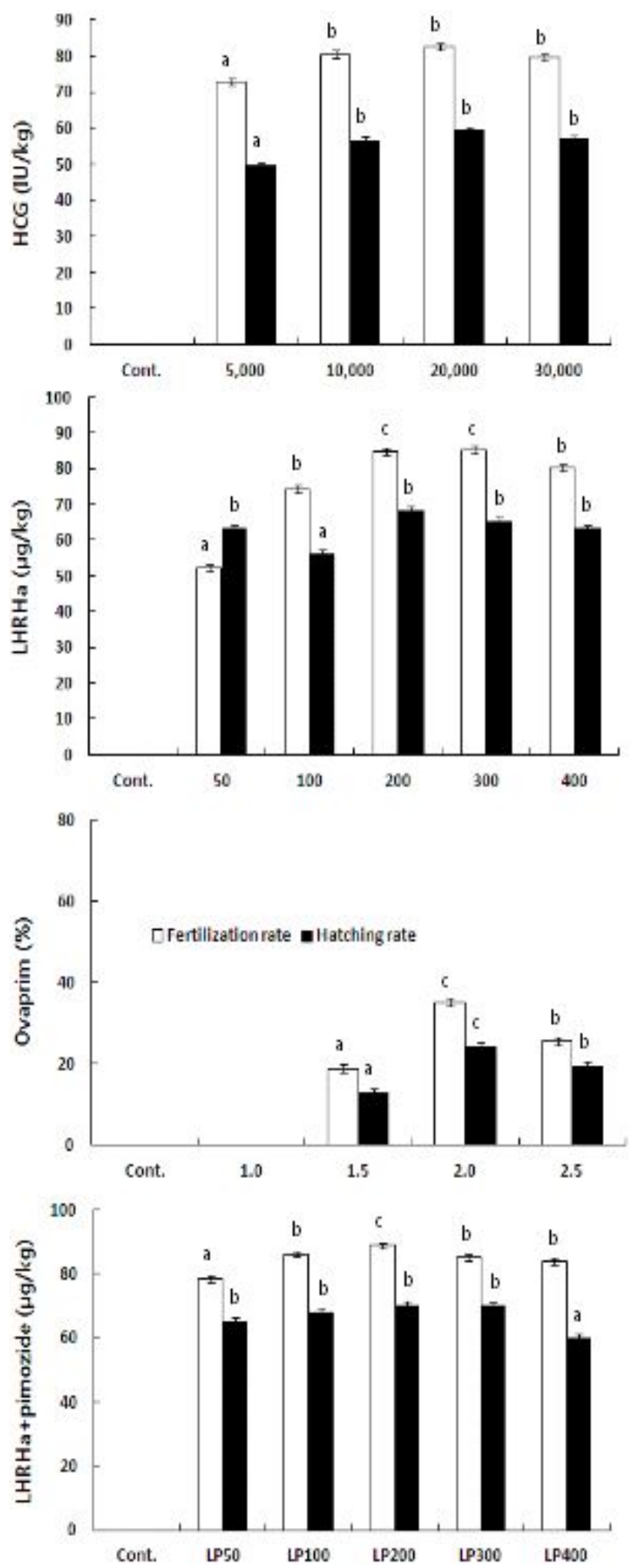

Fig. 2. Fertilization and hatching rates of ussirian bullhead in each hormones. Cont: control, LP: LHRHa+pimozide. controlling external environmental factors such as photoperiod and water temperature, or by injecting pituitary hormones such as hCG, LHRH, GnRH, and pimodize. However, it is known to be hard to induce natural spawning in fish belonging to Bagridae (Lim et al., 1997), and thus study on ovulation induction by hormones, rather than by photoperiod and water temperature regulation, is necessary. Unlike LHRHa or $\mathrm{GnRH}$ that indirectly works on pituitary, hCG induces ovulation by directly affecting the reproductive organs. By doing so, hCG becomes the cause of low egg quality and, if the ovulation time is skipped, postmature process is accelerated, affecting the fertilization and hatching rates (Kwon et al., 1996). Kwon's finding was supported by the results of this study, as the ovulation time is shorter when hCG is injected $(16-20 \mathrm{hr})$ than when LHRHa (23-34 hr), ovaprim (27-40 hr), or the combinations of LHRHa and pimozide $(22-36 \mathrm{hr}$ ) was injected. But in the study of long snout bullhead, ovulation time was $28-48 \mathrm{hr}$ when hCG was injected twice, $28-44 \mathrm{hr}$ when LHRHa was injected twice, 66 $-92 \mathrm{hr}$ when hCG was injected once, $66-86 \mathrm{hr}$ when ovaprim was injected, and $62-86 \mathrm{hr}$ when the combinations of LHRHa and pimozide was injected. As the times for ussurian bullhead are shorter than these results, it can be determined that even for same fish that belong to the Bagridae, different hormones and concentrations of hormones are needed to be adjusted. Also, as fertilization and hatching rates of hCG do not differ too much from other hormones'. This result is not consistent with the results from Lim et al., as Lim founded that, for ussurian bullhead, hCG accelerates ovulation by directly affecting the reproductive organs but it also lowers the quality of the eggs by doing so.

LHRHa is known to be 30-50 times more effective than natural LHRH (Park et al., 1998) and is also known to be effective in ovulation inducement in catfish (Kwon et al., 1996) and bullhead Pseudobagrus fulvidraco (Park et al., 1998). However, as it has been 
reported that final maturation and ovulation did not occur in the spotted halibut, Verasper variegatus (Baek et al., 2000), it seems like different hormones are effective in ovulation inducement in different species. In this study, too, except for the treatment with $50 \mu \mathrm{g} / \mathrm{kg}$ of LHRHa, the ovulation rate was higher than $62 \%$, fertilization rate was higher than $75 \%$, and hatching rate was higher than $56 \%$, while the ovulation rates were $50 \%$ at $200 \mu \mathrm{g} / \mathrm{kg}, 75 \%$ at $300 \mu \mathrm{g} / \mathrm{kg}$, and $100 \%$ at $400 \mathrm{\mu g} / \mathrm{kg}$ of LHRHa. The positive association between concentration and effectiveness of ovulation was observed and no ovulation occurred at concentrations less than $100 \mu \mathrm{g} / \mathrm{kg}$. These results were consistent with results from this study (Park et al., 1998).

As for Ovaprim, it has recently been used in ovulation induction in Gobiobotia macroephala (Ko et al., 2011), Pseudopungtungia tenuicorpa (Ko et al., 2012), and in Clarias gariepinus (Sharaf, 2012). In Sharaf's study, ovulation time of $9.9 \mathrm{hr}$, ovulation rate of $100 \%$, and hatching rate of $84 \%$ were observed when ovaprim was injected to African catfish, while in Lim et al., 2012 , ovulation time of $66-86 \mathrm{hr}$, fertilization and hatching rates of $56.8 \%$ and $30 \%$ were observed at 2.5 $\mathrm{ml} / \mathrm{kg}$ of ovaprim in long snout bullhead. Since these rates were the highest, it could be concluded that ovaprim is not suitable in ovulation inducement in long snout bullhead. However, in this study, high ovulation rate of over $80 \%$ was observed at concentrations higher than $2.0 \mu \mathrm{g} / \mathrm{kg}$ and fertilization and hatching rates were over $72 \%$ and $60 \%$, respectively. This shows that it is less effective than in African catfish but more effective than in long snout bullhead. Also, as the concentration increased from 1.0 to $3.0 \mathrm{ml} / \mathrm{kg}$, the ovulation time shortened from $36-40 \mathrm{hr}$ to $27-30 \mathrm{hr}$, while the fertilization rate increased, further studies on ovulation inducement at higher concentration of ovaprim would be needed.

The affordability and manageability of pimozide allow it to be used to induce ovulation and to be com- bined with hCG (Park et al., 1998; Song et al., 2008), GnRHa (Jang et al., 1998), and LHRHa (Park et al., 1998) to be used. In Bagridae, LHRHa by itself can be used for ovulation inducement, but when it is used with pimozide, the ovulation rate gets higher and use of LHRHa can be reduced. Generally, good results can be obtained when pimozide of $1,000 \mu \mathrm{g} / \mathrm{kg}$ and $200-$ $300 \mu \mathrm{g} / \mathrm{kg}$ of LHRHa are combined. But the ovulation rate of $100 \%$ and the highest fertilization and hatching rates of $78 \%$ and $60 \%$ were obtained at LHRHa concentration of $200 \mu \mathrm{g} / \mathrm{kg}$ in this study and this result does not stand out when compared to other experimental groups.

Therefore, all hormones showed similar results. But as hCG is easy to purchase and is affordable, it can be concluded that hCG is the most useful in obtaining stable fertilization eggs in the most effective way.

\section{ACKNOWLEDGEMENT}

This paper is a part of subject for development of ecofriendly aquaculture technology in rice fields (RP2012-AQ-108).

\section{REFERENCES}

Baek HJ, Kim Y, An CM, Cho KC, Myeong JI, Lee NJ (2000) Effects of hormonal treatment on induced maturation and ovulation in the spotted halibut, Varasper variegatus. J Aquacult 13:47-53.

Hwang KH, Lee JU, Yang SG, Rho S, Kang YJ (1999) Induced ovulation in rabbitfish, Siganus canaliculatus, with human chorionic gonadotropin (hCG). J Aquacult 12:197-204.

Jang SI (1996) Induced ovulation bu using human chorionic gonadotropin and gonadotropin-releasing hormone analogue plus pimozide in yellow puffer, Takifugu obscurus. J Aquacult 9:3-10.

Jang SI, Lee WO, Lee JY, Son SJ (1998) Induced 
Dev. Reprod. Vol. 16, No. 4 (2012) Induction of Ovulation by Hormone Treatment in Ussurian Bullhead Leiocassis ussuriensis 277

ovulation in the mandarin fish, Siniperca scherzeri by sex-maturation hormones. J Aquacult 11: 513-519.

Kim KH, Lee YH (2000) The ultrastructure of spermatozoa of the ussurlan bullhead, Leiocassis ussuriensis with phylogenetic consideration. Kor $\mathrm{J} \mathrm{Li}$ mnol 33:405-412.

Kang EJ, Lee BI, Cho MY, Sihn SG (2003) Difference inn the growth between male female og ussurien bullhead, Leiocassis ussuriensis. Kor J Ichthyol 15: 272-277.

Kim BH, Kim KM, Lee YD, Song CB, Rho S (1997) Reproductive biology of the sevenband grouper, Epinephelus septemfasciatus; The effect of hCG on ovulation induction. J Aquacult 10:55-61.

Ko MH, Kim WJ, Park SY, Bang IC (2011) Egg development and early life history of the endangered species Gobiobotia macrocephala (Cyprinidae). Kor J Ichthyol 23:198-205.

Ko MH, Park SY, Bang IC (2012) Egg development and early life history of the slender shinner, Pseudopungtungia tenuicorpa (Pisces: Cyprinidae). Kor J Ichthyol 24: 48-55.

Kwon HC, Choi NJ, Park HY (1996) Induced ovulation on catfish (Silurus asotus) by GnRH-Analogue. J Aquacult 9:205-213.

Lee WO, Kim KH, Kim DH, Cho YC, Kim EO (2004) Study of morphological characteristics and early life history of long snout bullhead, Leiocassis longirostris of introduced fish from China. Kor J Ichthyol 16:
42-50.

Lim SK, Baek HJ, Han CH (1997) Effects of steroids and hCG on in vitro maturation and ovulation of oocyte in banded catfish, Pseudobagrus fulvidraco. J Kor Fish 30:203-210.

Lim SG, Kim GS, Kim YS, Han HG, Kim EO (2012) Effect of hCG, LHRHa, ovaprim and pimozide on ovulation induction in long snout bullhead Leiocassis longirotris. Biol Reprod 16(2): 137-143.

Park HY, Lee JY, Lee YJ, Kwon HC (1998) Induction of ovulation by LHRH-a and pimozide in the bullhead, Pseudobagrus fulvidraco. J Aquacult 11: 151-158.

Park SY, Lee YA, Choi KC, Kang EJ, Bang IC (2001) Early gonadogenesis and sex differentiation in the bagrid catfish, Leiocassis ussuriensis. Kor J Ichthyol 13:248-253.

Sharaf SM (2012) Effect of GnRHa, pimozide and Ovaprim on ovulation and plasma sex steroid hormones in African catfish Clarias gariepinus. Theriogeno 77:1709-1716.

Song YB, Baek HJ, Kim HB, Soyano K, Kim SJ, Lee YD (2008) Induction of maturation and ovulation with hCG treatment in the sevenband grouper Epinephelus septemfasciatus. J Aquacult 21:96-101.

(Received 14 November 2012, Received in revised form 7 December 2012, Accepted 21 December 2012) 